\title{
PREDICTION OF CREATININE CLEARANCE FROM SERUM CREATININE IN SPINAL CORD INJURY PATIENTS
}

\author{
By M. K. Mirahmadi, C. Byrne, C. Barton, N. Penera, S. Gordon and \\ N. D. VAZIRI \\ Division of Nephrology, University of California, Irvine, California and SCI and \\ Medical Services, Long Beach VA Medical Center, Long Beach, California.
}

Summary. Measured endogenous creatinine clearance (Ccr) was compared with the predicted Ccr in 22 paraplegic, 36 tetraplegic and I I ambulatory male individuals as well as I I ambulatory females all of whom had normal renal function. While the predicted and measured values closely matched in the ambulatory patients the predicted values in the spinal cord injured patients consistently exceeded the measured values. It thus appears that the original Cockcroft and Gault formula;

$$
\text { Creatinine clearance }=\frac{(\mathrm{I} 40-\mathrm{Age}) \cdot(\mathrm{Wt} . \mathrm{kg} .)}{72 \cdot \mathrm{Scr}(\mathrm{mg} / \mathrm{IOOml})}
$$

when applied to SCI patients can be misleading. Modification of the original formula using a correction factor of 0.8 in paraplegics and 0.6 in tetraplegics was found to allow prediction of Ccr from age, sex, body weight, and serum creatinine in these patients with reasonable accuracy.

Key words: Spinal Cord Injury; Paraplegia; Tetraplegia; Serum creatinine; Creatinine clearance.

\section{Introduction}

SEVERAL methods of estimation of Ccr from serum creatinine values have been proposed (Edward and Whyle, I959; Jilliffe, I97I; Jilliffe, I973; Lott and Hayton, I978; Parker et al., I980; Sierback-Nielsen et al., I97 I). Recently, Cockcroft and Gault (Cockcroft and Gault, I976) reported on accurate prediction of $\mathrm{Ccr}$ in ambulatory patients from age, sex, weight and serum creatinine concentration. Since the proportion of muscle mass to total body weight in patients with spinal cord injury (SCI) may be substantially less than that of ambulatory patients, some modification of the original formula may be required when applied to the SCI patients.

The present study was intended to examine the validity of the Cockcroft and Gault formula in SCI patients, and to identify the necessary correction factors for its use in this population.

\section{Patients and Methods}

Fifty-eight male hospitalized SCI patients, twenty-two paraplegics and thirty-six tetraplegics, without evidence of significant proteinuria or renal impairment were studied. The urinary flow was provided with either in-

Reprint requests: N. D. Vaziri, M.D., Division of Nephrology, Department of Medicine, University of California Irvine Medical Center, IO I City Drive South, Orange, CA 92668. 
dwelling catheters, suprapubic catheter or nephrostomy tubes. A control group of twenty-two ambulatory patients without significant proteinuria or renal insufficiency (eleven males, and eleven females) were also included. All patients were clinically stable and their serum creatinine concentrations ranged between 0.5 to $2.0 \mathrm{mg} / \mathrm{dl}$. Accurately collected 24-hour urine samples were used for measurement of endogenous Ccr. Serum and urinary creatinine determinations were performed using an autoanalyser. Predicted Ccr was calculated using the Cockcroft and Gault formula (Cockcroft and Gault, I976):

$$
\mathrm{Ccr}=\frac{(\mathrm{I} 40-\mathrm{Age}) \cdot(\mathrm{Wt})}{72 \cdot \text { Serum Cr}}
$$

A I 5 per cent correction was used for females, by multiplying body weight by 0.85 as recommended by the authors (Cockcroft and Gault, I976). The measured Ccr was divided by the predicted Ccr and the mean of the observed ratios was determined to represent the proposed correction factor for each group of the SCI patients. The error in accuracy of the model was determined from the predicted minus measured creatinine clearances. The 95 per cent confidence limits on the precision were determined by the formula:

\section{Confidence limits $= \pm \mathrm{t}$. SEM}

Where $t$ is the student's t-value at the given degrees of freedom, and SEM is the standard error of the mean of the predicted-measured values. It should be noted that the confidence limits refer to the formula, and not the individual patients.

\section{Results}

The SCI patients consisted of 22 paraplegic and 36 tetraplegics, whose average age was 48 and 46 years, respectively. The respective values for body weight and duration of SCI in paraplegics was $7 \mathrm{I} \mathrm{kg}$ and $\mathrm{I} 4$ years. The average body weight in the tetraplegics was $68 \mathrm{~kg}$, and the average duration of SCI was ten years. The paraplegic group had a significantly higher serum creatinine and daily urinary creatinine excretion per kg body weight than the tetraplegics. The serum creatinine levels were $\mathrm{I} \cdot 0 \pm 0 \cdot 4$ and $0.8 \pm 0.3 \mathrm{mg} / \mathrm{dl}$ in the paraplegics and the tetraplegics respectively $(\mathrm{P}<0.05)$. The respective values for 24 -hour urinary creatinine excretion were I $6 \pm 9$ and I I $\pm 4.6 \mathrm{mg} / \mathrm{kg}$ in the two groups $(\mathrm{P}<0.02)$. There was no significant differences in serum urea nitrogen levels between the two groups. The relevant clinical data for the SCI group are displayed in Table I.

The control group consisted of I I men and I I women whose average ages were 39 and 42 years respectively. The body weight averaged $73 \mathrm{~kg}$ in the male control group and $62 \mathrm{~kg}$ in the females group. The average serum creatinine was $1.5 \mathrm{mg} / \mathrm{dl}$, and the 24-hour urinary creatinine excretion was $20 \mathrm{mg} / \mathrm{kg}$ the male control group. The respective values in the female group were I.I $\mathrm{mg} / \mathrm{dl}$ and $\mathrm{I} 8 \mathrm{mg} / \mathrm{kg}$ body weight. The clinical data for the control group are displayed in Table II.

The predicted creatinine clearance was calculated for all groups. An adjustment was made for the female control group by multiplying the body 
TABLE I

Clinical data in 58 SCI patients

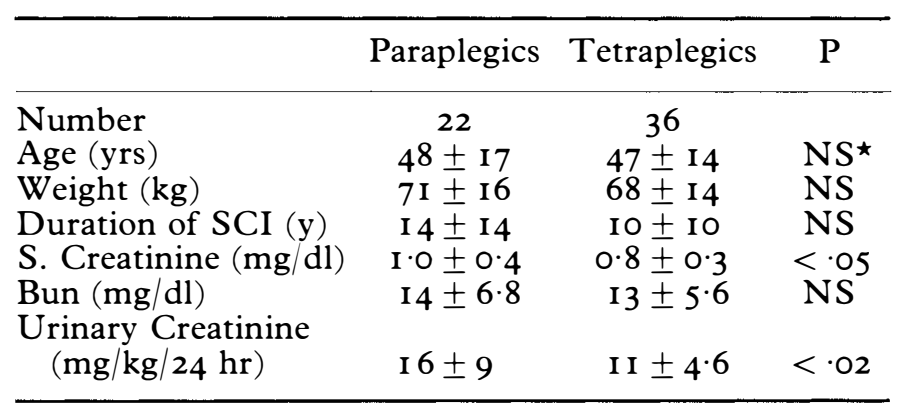

* Not significant

TABLE II

Clinical data on 22 control patients

\begin{tabular}{lccl}
\hline & Male & Female & $P$ \\
\hline $\begin{array}{l}\text { Number } \\
\text { Age (yrs) }\end{array}$ & I I & I I & \\
Weight $(\mathrm{kg})$ & $39 \pm \mathrm{I} 5$ & $42 \pm \mathrm{I} 7$ & $\mathrm{NS}$ \\
$\begin{array}{l}\text { S. Creatinine }(\mathrm{mg} / \mathrm{dl}) \\
\begin{array}{l}\text { Urinary Creatinine } \\
(\mathrm{mg} / \mathrm{kg} / 24 \mathrm{hr})\end{array}\end{array}$ & $\mathrm{I} \cdot 5 \pm 0.7$ & $\mathrm{I} \cdot \mathrm{I} \pm 0.3$ & $\mathrm{NS}$ \\
\hline
\end{tabular}

^ Not significant

weight by 0.85 (Cockcroft and Gault, I976). The measured to predicted ratio averaged 0.8 in paraplegics and 0.6 in the tetraplegic group. The ambulatory male population had a measured Ccr of $82 \pm 39 \mathrm{ml} / \mathrm{min}$ and a predicted Ccr of $77 \pm 29 \mathrm{ml} / \mathrm{min}$. The error in accuracy was $-5 \mathrm{ml} / \mathrm{min}$, the 95 per cent spread of precision was $\pm 9 \mathrm{ml} / \mathrm{min}$ and the correlation coefficient $(\mathrm{r})$ was $0.97(\mathrm{P}<0.00 \mathrm{I})$. The measured $\mathrm{Ccr}$ in female controls was $70 \pm \mathrm{I} 6 \mathrm{ml} / \mathrm{min}$ while the adjusted predicted Ccr was $70 \pm 23 \mathrm{ml} / \mathrm{min}$. The error in accuracy was $0 \mathrm{ml} / \mathrm{min}$, the 95 per cent precision was $\pm \mathrm{I} 0 \mathrm{ml} / \mathrm{min}$ and the $\mathrm{r}$ value was $0.77(\mathrm{P}<0.0 \mathrm{I})$ in this group.

The measured Ccr was $82 \pm 46 \mathrm{ml} / \mathrm{min}$, and the predicted value calculated from the original formula was $102 \pm 48 \mathrm{ml} / \mathrm{min}$ in the paraplegic patients. The error in accuracy was $20 \mathrm{ml} / \mathrm{min}$, the 95 per cent confidence was $\pm I 2 \mathrm{ml} / \mathrm{min}$ and the correlation coefficient was 0.82 $(\mathrm{P}<0.00 \mathrm{I})$. When corrected the predicted $\mathrm{Ccr}$ for the paraplegic group was $82 \pm 36 \mathrm{ml} / \mathrm{min}$ with no error in accuracy and a 95 per cent confidence of $\pm \mathrm{I} 2 \mathrm{ml} / \mathrm{min}$. The slope between the adjusted and the measured values was $\mathrm{I} \cdot 00$ with $\mathrm{r}=0.82(\mathrm{P}<0.00 \mathrm{I})$. The measured $\mathrm{Ccr}$ in tetraplegics was $70 \pm 23 \mathrm{ml} / \mathrm{min}$, while the unadjusted predicted value was I I $7 \pm 43$ $\mathrm{ml} / \mathrm{min}$ with an error in accuracy of $47 \mathrm{ml} / \mathrm{min}$. When adjusted, the predicted Ccr was $70 \pm 26 \mathrm{ml} / \mathrm{min}$ with no error in accuracy, but a spread in precision of $\pm 25 \mathrm{ml} / \mathrm{min}$ and $\mathrm{r}=0.59(\mathrm{P}<0.00 \mathrm{I})$. The slope between 
TABLE III

Results of correlation between predicted and measured creatinine clearance

\begin{tabular}{|c|c|c|c|c|c|c|}
\hline & $\begin{array}{l}(\mathrm{X}) \\
\text { Predicted } \\
\text { creatinine } \\
\text { clearance }\end{array}$ & $\begin{array}{l}(\mathrm{Y}) \\
\text { Measured } \\
\text { creatinine } \\
\text { clearance }\end{array}$ & Slope & $\begin{array}{c}(\mathrm{Y}) \\
\text { Intercept }\end{array}$ & $\mathrm{r}$ & $\mathrm{P}$ \\
\hline Male & $77 \pm 29$ & $82 \pm 39$ & $I \cdot 29$ & $-17 \cdot 5$ & 0.97 & $P<0.001$ \\
\hline Female (before) & $83 \pm 27$ & $70 \pm 16$ & 0.45 & $32 \cdot 6$ & 0.77 & $P<0.0 I$ \\
\hline (after correction) & $70 \pm 23$ & $70 \pm 16$ & 0.53 & $32 \cdot 6$ & 0.77 & $\mathrm{P}<0.0 \mathrm{I}$ \\
\hline Para. (before) & IO2 \pm 48 & $82 \pm 46$ & 0.84 & $33 \cdot 8$ & 0.82 & $\mathrm{P}<0.00 \mathrm{I}$ \\
\hline (after correction) & $82 \pm 38$ & $82 \pm 46$ & $I \cdot 00$ & 0.3 & 0.82 & $P<0.00 I$ \\
\hline Tetra. (before) & I $17 \pm 43$ & $70 \pm 23$ & 0.40 & $23 \cdot 0$ & 0.68 & $\mathrm{P}<0.00 \mathrm{I}$ \\
\hline (after correction) & $70 \pm 26$ & $70 \pm 23$ & 0.74 & $18 \cdot 5$ & 0.59 & $\mathrm{P}<0.00 \mathrm{I}$ \\
\hline
\end{tabular}

the predicted and measured values was 0.74 with a $\mathrm{Y}$-intercept of $\mathrm{I} 8.5$ (Table III).

\section{Discussion}

Serious bacterial infection and renal insufficiency are common complications of spinal cord injury with the former being the leading cause of death in these patients, since the development and application of supportive dialysis (Mirahmadi et al., I977; Mirahmadi et al., I982; Tribe and Silver, 1969). Treatment often includes the administration of potentially toxic drugs which are excreted by the kidney. Aminoglycoside antibiotics, frequently used in this setting for various gram negative infections, possess ototoxic and nephrotoxic properties and are of particular concern. Careful dose adjustment, therefore, based on measurement or estimation of glomerular filtration rate (GFR) and periodic measurement of serum levels of the antibiotic are essential in reducing the risk of toxicity. In view of the need for frequent monitoring of renal function a quick and convenient means of assessing renal function is, therefore, desirable especially since the established methods of estimating GFR i.e. inulin and creatinine clearances are costly, time consuming and associated with certain other problems (Miller and Winkler, I938; Dodge et al., I967).

Inulin clearance is not routinely used in the clinical setting, due to the following problems:

I. Need for an intravenous line and constant inulin infusion;

2. Lack of serum and urine inulin assay capability in most clinical laboratories; and

3. High cost and length of the procedures involved.

Price et al., reported that creatinine clearance determined using autoanalyser-Jaffe method closely parallels the inulin clearance in SCI patients without discernible kidney damage (Price et al., 1967). Endogenous creatinine clearance, commonly used to assess GFR, suffers from several drawbacks:

I. The method requires a timed urine collection;

2. The procedure is cumbersome and subject to errors at multiple 
stages and often associated with relatively low precision and reproducibility; and finally

3. urinary creatinine assay, necessary to determine Ccr, may not be readily available in some facilities during nights, weekends, and holidays.

It is thus apparent that a method of estimation of GFR which is quick, convenient and accurate would have obvious utility.

It is well established that renal function may diminish with aging without a concomitant rise in serum creatinine level due to the age-induced reduction of muscle mass. Reduced creatinine production with age is evidenced by the demonstrated fall in 24-hour urinary creatinine excretion per kilogram of body weight from $24 \mathrm{mg} / \mathrm{kg}$ at age 20 to I $2 \mathrm{mg} / \mathrm{kg}$ at age 80 (Cockcroft and Gault, I976; Davies and Shock, I950; Papper, I973, Rowe et al., I976; Rowe, 1978).

In addition to age, total body weight influences the creatinine generation and thereby the serum creatinine levels for any given level of GFR. Both these variables have been incorporated in the Cockcroft and Gault formula. Another variable to be considered is the proportion of the muscle mass to the total body weight which is lower in females compared to males. Cockcroft and Gault have, therefore, incorporated a I 5 per cent (IO-20 per cent) adjustment $(0.85$. weight in kilograms) for prediction of Ccr in females. While Gral and Young (Gral and Young, I980) did not find this correction to be necessary in their series our data supports the need for such adjustment as suggested by Cockcroft and Gault (Cockcroft and Gault, I976). Due to severe muscle atrophy the ratio of muscle mass to total body weight in spinal cord injured patients is much less than that of the ambulatory individuals. The degree of the reduction of muscle mass relative to the total body weight is much more severe in tetraplegics than paraplegics. This is evidenced by the observed differences in urinary creatinine excretion averaging I I $\mathrm{mg} / \mathrm{kg} / 24 \mathrm{hr}$ in tetraplegics versus I $6 \mathrm{mg} /$ $\mathrm{kg} / 24 \mathrm{hr}$ in paraplegics. The adjustment of 20 per cent $(0.8$. weight $)$ for paraplegics and 40 per cent $(0.6$. weight) for tetraplegics proposed in this paper provides the necessary correction in these patients. In the Cockcroft and Gault formula the denominator is 72 . serum creatinine $(\mathrm{mg} / \mathrm{dl})$, therefore, the effect of inaccuracy in serum creatinine determination on the predicted Ccr is markedly exaggerated. Serum creatinine levels in some of our tetraplegic patients, were so low $(0.2-0.4 \mathrm{mg} / \mathrm{dl})$ that they could not be accurately measured with the autoanalyser method. Therefore, predicted Ccr values with serum creatinine levels below $0.5 \mathrm{mg} / \mathrm{dl}$ may not be reliable. The patients with serum creatinine levels below $0.5 \mathrm{mg} / \mathrm{dl}$ were, therefore, excluded from the present study. The actual measurement of creatinine clearance using timed urine collection is the preferred method in such patients.

To evaluate the precision and accuracy of the models we used linear correlations the results of which are displayed in Table III. The success of a correction factor was verified by the following observations:

I. An improvement in accuracy as demonstrated by the fact that the quantity of Predicted Ccr minus Measured Ccr decreased or approached zero;

2. The slope of a linear correlation between the predicted and measured values approached one, 
3. The Y-intercept of a linear correlation between the predicted and measured values was minimised and;

4. The measurement of precision or confidence of the model improved.

It should be noted that the correlation coefficient, $r$, and hence the significance level, $\mathrm{P}$, do not change greatly when the values are multiplied by constants. An improvement in the model will not be, therefore, reflected by changes in these values.

A decrease in the precision (95 per cent confidence limit) in the corrected model of the tetraplegics is probably a reflection of the heterogeneity of muscle mass/body weight and possibly other factors in this group. Nonetheless, the correction factors introduced by the present study improved the accuracy and precision of the predicted Ccr values enabling extension of this prompt and easy method to SCI populations with, reasonable accuracy.

\section{RÉSUMÉ}

Nous avons compare la clearance de creatinine endogene mesuree avec la clearance de creatinine estimee pour 22 patients paraplegiques, 36 quadriplegiques, I I hommes et I I femmes ambulatoires tous a fonctions renales normals. Chez les personnes ambulatoires les valeurs estimees sont tres proches aux valeurs mesurees, tandis que les valeurs estimees chez les patients avec des blessures de la colonne vertebrale etaient toujours superieures aux valeurs mesurees. Il semble donc que la formule de Cockcroft et Gault:

$$
\text { clearance de creatinine } \frac{(140-\mathrm{age}) .(\text { poids, } \mathrm{kg})}{72 \text {. creatinine serique }(\mathrm{mg} / \mathrm{I} 00 \mathrm{ml})}
$$

peut etre incorrecte si elle est appliquee aux patients avec des blessures de la colonne vertebrale. Une modification de la formule originale par un facteur de 0.8 pour le patients paraplegiques et un facteur de 0.6 pour les patients quadriplegiques, permet une prediction assez precise de la clearance de creatinine a base de l'age, sexe, poids, et creatinine serique.

\section{ZUSAMMENFASSUNG}

Gemessene endogene Kreatinin-Clearance wurde verglichen mit der geschatzten KreatininClearance von 22 Paraplegikern, 36 Quadriplegikern und I I ambulanten mannlichen, als auch I I ambulanten weiblich Individuen, alle mit normaler Nierenfunktion. Wahrend die geschatzten und gemessenen Werte bei ambulanten Patienten nahe ubereinstimmten, lagen die geschatzten Werte von Patienten mit Wirbelsauleverletzungen hoher als die gemessenen Werte. Es schient das die Originalformel von Cockcroft und Gault:

$$
\text { Kreatinin-Clearance }=\frac{(\mathrm{I} 40-\text { Alter })}{72 . \text { Serumkreatinin }(\mathrm{mg} / \mathrm{IOOml})}
$$

wenn bei Patienten mit Wirbelsauleverletungen angewendet, zu falschen Folgerungen fuhren kann. Eine Modifikation der Originalformel mit einem Korrekturfaktor von 0.8 fur Paraplegiker und 0.6 fur Quadriplegiker erlauben eine zuverlassige Schatzung von Kreatinin-Clearance an Hand von Alter, Geschlecht, Korpergewicht und Serumkreatinin.

\section{REFERENCES}

CockCroft, D. W. \& Gault, M. H. (1976). Prediction of creatinine clearance from serum creatinine. Nephron., I6, 3I-4I.

Davies, D. E. \& SHOCK, N. W. (1950). Age changes in glomerular filtration rate, effective renal plasma flow and tubular excretory capacity in adult males. F. Clin. Invest., 29, 496-507. 
Dodge, W. F., Travis, L. B., \& Daeshner, E. N. (1976). Comparison of endogenous creatinine clearance with inulin clearance. Am. F. Dis. Child., 113, 683-692.

EDWARD, K. D. G. \& Whyle, H. M. (1959). Plasma creatinine level and creatinine clearance as tests of renal function. Australian Ann. Med., 8, 2 I 8-233.

GraL, T. \& Young, M. (I980). Measured versus estimated creatinine clearance in the elderly as an index of renal function. F. Am. Geri. Soc., 28, 492-496.

JiLLIFFE, R. W. (I97I). Estimation of creatinine clearance when urine cannot be collected. Lancet, I, 975-976.

Jilliffe, R. W. (I973). Creatinine clearance. Bedside estimate. Ann. Intern. Med., 79, 604-605.

LotT, R. S. \& Hayton, W. L. (I978). Estimation of creatinine clearance from serum creatinine concentration-A review. Drug Intell. and Clin. Pharm., 12, I40-I 50.

MilleR, B. F. \& WINKLER, A. W. (1938). The renal excretion of endogenous creatinine in man: Comparison with exogenous creatinine and inulin. f. Clin. Invest., 17, 3 I40.

Mirahmadi, K. S., Winer, R. L., Gorman, J. T., Sawhney, A. S., Sankaram, R. S., Williams, T. \& Kaplan, M. S. (I977). Hemodialysis in spinal cord injury patients with chronic renal failure. Dialysis $\mathcal{E}$ Transplantation, 6, 6-9.

Mirahmadi, M. K., Vaziri, N. D., Ghobadi, M., Nikakhtar, B., \& Gordon, S. (1982). Survival on maintenance dialysis in patients with chronic renal failure associated with paraplegia and quadriplegia. Paraplegia, 2o, 43-47.

PAPPER, S. (1973). The effects of age in reducing renal function. Geriatrics, 28, $83-\mathrm{F}$.

Parker, R. A., Bennett, W. M. \& Porter, G. A. (I980). Clinical estimation of creatinine clearance without urine collection. Dialysis $\mathcal{E}$ Transplantation, 9, 25I-252.

Price, M., Pilsum, J., Marklund, C. \& Boen, J. R. (Sept 1967). Comparisons of creatinine clearance with inulin clearance in paraplegic patients. Proc. Annu. Clin. Spinal Cord Injury Conference, 16, I76-1 80.

Rowe, J. W., ANDREs, R., Tobin, J. D. et al. (1976). The effect of age on creatinine clearance in men: a cross-sectional and longitudinal study. F. Gerontol., 31, I 55-163.

Rowe, J. W. (1978). The influence of age on renal function. Resident and Staff Physician, 24, 2. 49-55.

Sierback-Nielsen, F., Molholn, J., Kampmann, J. et al. (I97I). Rapid evaluation of creatinine clearance. Lancet, I, I333-1334.

Tribe, C. R. \& Silver, J. R. (I969). Renal Failure in Paraplegia, pp. 3-I8. Pitman, London.

This Study was generously funded by the late Eldore G. ReINIS. 